\title{
Knowledge, Attitude and Practice of Hepatitis-B Vaccination among Clinical Medical Students at a Medical College in Nepal
}

Subash Bhattarai ${ }^{1}$, Merina Gyawali ${ }^{2}$, Subash Sapkota ${ }^{3}$, Dipesh Karki ${ }^{4}$, Sudip Lamsal ${ }^{5}$

Author Info:

${ }^{1}$ Associate Professor, ${ }^{2,3,4}$ Assistant

Professor, ${ }^{5}$ Resident

1,3,4,5 Department of Medicine, ${ }^{2}$ Department of Radiodiagnosis and Imaging; Manipal College of Medical Sciences, Pokhara, Nepal.

\section{Corresponding Author: \\ Dr Subash Bhattarai}

Unit of Gastroenterology, Department of Medicine,

Manipal College of Medical Sciences and Teaching Hospital, Pokhara, Nepal

Email: kiwisubash@yahoo.com Mobile No: +9779815293117

\begin{abstract}
Background: Hepatitis B vaccine is the single most effective and safest strategy for the prevention of the disease among health care workers (HCW), trainees and medical students. There is scanty information on knowledge, attitude and practice (KAP) regarding Hepatitis B vaccination among medical students who are likely to get exposed in the future as they start practicing. This study was undertaken to understand the knowledge, attitude and practice of hepatitis $B$ vaccination among clinical medical students of Manipal College of Medical sciences at Pokhara, Nepal.
\end{abstract}

Methods: Two hundred and four medical students were enrolled for a descriptive cross-sectional study at Manipal College of Medical sciences at Pokhara, Nepal after obtaining ethical clearance from Institutional Review Committee. Answers to pre-tested questionnaire were collected. Knowledge, attitude and practice regarding Hepatitis B vaccination were studied.

Results: All participants demonstrated good knowledge and positive attitude towards Hepatitis B infection and vaccination. However majority had poor practice towards it. Only $47.1 \%$ were completely vaccinated. The most common reason for non vaccination was that many thought they will vaccinate in internship or when they start practicing.

Conclusions: Despite good knowledge and positive attitude towards Hepatitis $B$ infection and vaccination, low rates of vaccination and poor practice was observed among medical students indicating the necessity of encouragement for vaccination and proper practices among them. All medical students should be immunized against Hepatitis B during their medical school. Regular Hepatitis $B$ vaccination, educational and awareness programs must be conducted in coordination and with active participation of the medical students.

Keywords: Attitude; Hepatitis-B; Knowledge; Medical Students; Practice; Vaccination

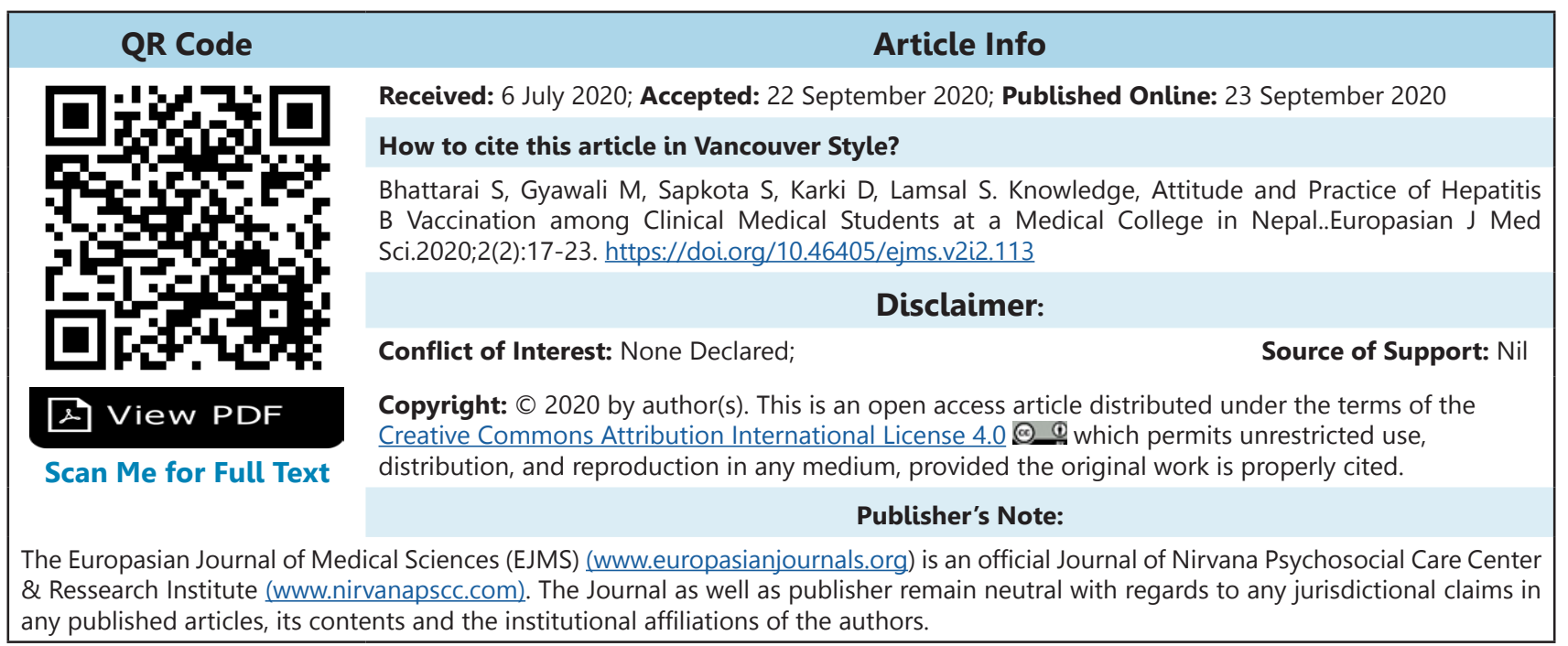




\section{INTRODUCTION}

Hepatitis-B virus (HBV) infection is a worldwide healthcare problem. ${ }^{1}$ About $10 \%$ of the patients develop chronic hepatitis and about 15\%-25\% develop cirrhosis after infection with HBV. ${ }^{2,3}$ National study on HBV has shown upto $2.7 \%$ prevalence among high risk group with injecting drugs in Western Nepal. ${ }^{4}$ Hepatitis B is the major infectious occupational health hazard for hospital staffs because of their repeated exposure. ${ }^{5}$ All the hospital staffs including trainees and medical students are at occupational risk of HBV infection. The risk of accidental exposure among the trainees could be even higher due to their non experience, insufficient training and lack of preventive knowledge. $^{5}$

Hepatitis B virus infection is one of the most preventable causes of chronic liver disease. ${ }^{5}$ Hepatitis $B$ vaccine is the single most effective and safe strategy for the prevention of the disease. $^{6}$ World Health Organization (WHO) has recommended vaccination to people at occupational risks of Hepatitis B virus infection. ${ }^{7}$ Despite of high occupational risk among health professionals, the WHO estimate showed that HBV vaccination coverage among Health care workers (HCW) is low worldwide. ${ }^{7}$

Studies regarding the prevailing knowledge, attitude and practice of Hepatitis $B$ vaccination among medical students within the country are scanty. This study was therefore carried out to determine the knowledge, attitude and practice of Hepatitis B vaccination among clinical medical students at Manipal College of Medical Sciences at Pokhara, Nepal.

\section{MATERIALS AND METHODS}

This descriptive, cross-sectional study was conducted at Manipal College of Medical Sciences and Teaching Hospital at Pokhara, Gandaki Province from $1^{\text {st }}$ June to 30th June 2020, over a period of 1 month. The study was conducted after obtaining ethical clearance from Institutional Research Committee (MEMG/IRC/334/GA) and informed consent from study participants.

The college runs an undergraduate MBBS programme and recruits a batch of 100 students each year. Previous batches, including this study batch contained 135 medical students. All clinical medical students of 3rd and 4th (Final) year MBBS were enrolled in the study. Subjects who were absent during the study period and those who did not return the questionnaire were excluded from the study. This included pre-tested questionnaire that were categorized into 3 sections: section 1knowledge, section 2- attitude, section 3- practice of Hepatitis $B$ vaccination. Each correct response was scored as one mark and incorrect or non response was scored zero. Level of knowledge was graded as good or adequate for participants who scored $\geq 50 \%$ and poor when $<50 \%$. Similarly, for attitudes and practices, participants achieving $\geq 50 \%$ were classified as having positive attitudes and safe practices, respectively and $<50 \%$ as having negative attitude and poor practices.

The data analysis was done using SPSS Version 16. All categorical data were expressed in percent and absolute number. All numerical continuous data were expressed in mean \pm SD. Chi squared test / fisher exact test were used to test for significant difference of proportions and mean. All tests were analyzed with a 95\% confidence interval and a $\mathrm{p}$ value of $<0.05$ was considered significant.

\section{RESULTS}

The semi structured questionnaire was distributed to 214 MBBS clinical medical students at Manipal College of Medical Sciences. However they were returned and answered by only 204 medical students. The response rate was thus $95.3 \%$. The study participants comprised of 122 males and 82 females (M: $F=3: 2$ ). The mean age of study participants was $24.2 \pm .3 .25$ years. The study participants comprised of 112 students from 1st clinical year (i.e. 3rd year MBBS) and 92 students from 2nd clinical year (Final or 4th year MBBS).

\section{Knowledge, attitude and practice about Hepatitis B vaccination}

Majority comprising of 195 (95.6\%) respondents had good knowledge of Hepatitis B infection and vaccination. Majority comprising of 198 (97.1\%) respondents had positive attitude. The mean knowledge and attitude scores of the study subjects were $73.92 \pm 17.57$ and $82.16 \pm 12.6$ respectively. Despite good knowledge and good attitude, majority of 175 (85.8\%) respondents had poor practice against Hepatitis B infection and vaccination. The mean practice score of the study subjects was $35.29 \pm 18.02$ (Table 1$)$.

All 204 (100\%) medical students had this knowledge that Hepatitis B virus can be acquired through needle stick injury. Majority comprising of $170(83.3 \%)$ respondents knew that Hepatitis B is not spread by handshaking .Only 146 (47.1\%) knew that Hepatitis B was 50-100 times more infectious than HIV. One hundred and sixty $(78.4 \%)$ students 
Table 1: Grading of Knowledge, Attitude and Practice of Hepatitis B Vaccination

\begin{tabular}{|l|l|l|l|}
\hline Grade & $\begin{array}{l}\text { Knowledge } \\
\text { Frequency (\%) }\end{array}$ & $\begin{array}{l}\text { Attitude } \\
\text { Frequency (\%) }\end{array}$ & $\begin{array}{l}\text { Practice } \\
\text { Frequency (\%) }\end{array}$ \\
\hline Good (score $\mathbf{2 5 0 \% )}$ & $195(95.6)$ & $198(97.1)$ & $29(14.2)$ \\
\hline Poor (score $\mathbf{5 0 \% )}$ & $9(4.4)$ & $6(2.9)$ & $175(85.8)$ \\
\hline Total & $204(100)$ & $204(100)$ & $204(100)$ \\
\hline Mean score (\%) & $73.92 \pm 17.57$ & $82.16 \pm 12.6$ & $35.29 \pm 18.02$ \\
\hline
\end{tabular}

knew about effective Hepatitis B vaccine but only $158(77.5 \%)$ knew its recommended schedule. Its effectiveness was known to $163(79.9 \%)$ but only $82(40.2 \%)$ knew that it could provide protection for at least 20 years. Post vaccination test is necessary to detect the immunization status and the value must be $>10 \mathrm{IU} / \mathrm{ml}$ were known to $134(65.7 \%)$ and 88(43.1\%) respectively. (Table 2 )

\section{Attitude towards Hepatitis B vaccination}

Majority comprising of 198 (97.1\%) respondents had positive attitude towards Hepatitis B infection and vaccination. The mean attitude score of the study subjects was $80.59 \pm 12.83$ (Table 2). Majority comprising of 186 (90.2\%) respondents informed that they might be at risk once they start practicing after completing medical school and all medical students felt that they need to be protected against Hepatitis B. Majority comprising of 165 (80.9\%) respondents considered it was a safe vaccine and 147 (72.1\%) trusted its efficacy. All students believed that vaccination must be compulsory to all medical students before they complete their medical school, 188(92.1\%) felt that more students would be vaccinated if provided for free and 183(89.7\%) believed that regular vaccination campaigns must be conducted in the hospitals. Majority comprising of 194 (95.1\%) respondents were willing to receive or complete their Hepatitis B vaccination if not vaccinated or incompletely vaccinated and 161 (78.9\%) would recommend vaccination to their friends at work (Table 3).

Table 2: Knowledge about Hepatitis B vaccination in study participants

\begin{tabular}{|c|c|c|c|}
\hline Variables & $\begin{array}{l}\text { 3rd MBBS }(\mathrm{N}=112) \\
\text { correct response }(\%)\end{array}$ & $\begin{array}{l}\text { 4th } \mathrm{MBBS}(\mathrm{N}=92) \\
\text { correct response }(\%)\end{array}$ & $\begin{array}{l}\text { Total }(\mathrm{N}=204) \text { correct } \\
\text { response }(\%)\end{array}$ \\
\hline $\begin{array}{l}\text { Hepatitis B virus can be acquired through } \\
\text { a needle stick injury }\end{array}$ & $112(100)$ & $92(100)$ & $204(100)$ \\
\hline $\begin{array}{l}\text { Hepatitis B Virus is not spread by hand } \\
\text { shaking }\end{array}$ & $96(85.7)$ & $74(80.4)$ & $170(83.3)$ \\
\hline $\begin{array}{l}\text { Hepatitis } B \text { is } 50-100 \text { times more } \\
\text { infectious than HIV }\end{array}$ & $44(39.3)$ & $52(56.5)$ & $96(47.1)$ \\
\hline There is effective vaccine for hepatitis B & $76(67.9)$ & $84(91.3)$ & $160(78.4)$ \\
\hline $\begin{array}{l}\text { Hepatitis } B \text { vaccine dosing } 0,1,6 \text { months } \\
: 3 \text { doses }\end{array}$ & $72(64.3)$ & 86(93.5) & $158(77.5)$ \\
\hline $\begin{array}{l}\text { Complete dose of Hepatitis B vaccine is } \\
95 \% \text { effective }\end{array}$ & $77(68.7)$ & $86(93.5)$ & 163(79.9) \\
\hline It provides protection for at least 20 years & $40(35.7)$ & $42(45.6)$ & $82(40.2)$ \\
\hline $\begin{array}{l}\text { A patient who has fully recovered cannot } \\
\text { infect others }\end{array}$ & $62(60.1)$ & $68(73.9)$ & $130(63.7)$ \\
\hline $\begin{array}{l}\text { Post Hepatitis B vaccination test is } \\
\text { necessary }\end{array}$ & $60(53.6)$ & $74(80.4)$ & $134(65.7)$ \\
\hline $\begin{array}{l}\text { For protection against Hepatitis } B \text {, one } \\
\text { needs antibody titer of }>10 \mathrm{IU} / \mathrm{ml}\end{array}$ & $40(35.7)$ & $48(52.2)$ & $88(43.1)$ \\
\hline
\end{tabular}




\begin{tabular}{|c|c|c|c|}
\hline Variables & $\begin{array}{l}\text { 3rd MBBS }(\mathrm{N}=112) \\
\text { positive response }(\%)\end{array}$ & $\begin{array}{l}\text { 4th } \mathrm{MBBS}(\mathrm{N}=92) \\
\text { positive response }(\%)\end{array}$ & $\begin{array}{l}\text { Total }(\mathrm{N}=204) \\
\text { positive response }(\%)\end{array}$ \\
\hline Will you be at risk as you work? & $96(85.7)$ & $88(95.6)$ & 184(90.2) \\
\hline $\begin{array}{l}\text { Do you feel you need to be protected } \\
\text { against Hepatitis B infection }\end{array}$ & $112(100)$ & $92(100)$ & 204(100) \\
\hline Is Hepatitis B vaccine safe? & $87(77.7)$ & $78(84.8)$ & 165(80.9) \\
\hline Trust efficacy of Hepatitis B vaccine & $71(63.4)$ & $76(82.6)$ & $147(72.1)$ \\
\hline $\begin{array}{l}\text { Hepatitis B vaccination should be } \\
\text { made compulsory in medical school }\end{array}$ & $112(100)$ & $92(100)$ & $204(100)$ \\
\hline $\begin{array}{l}\text { If vaccine provided by free from } \\
\text { medical school, more HCW will be } \\
\text { vaccinated }\end{array}$ & $1046(92.8)$ & $84(91.3)$ & 188(92.1) \\
\hline $\begin{array}{l}\text { Regular vaccination campaigns must } \\
\text { be conducted in medical schools }\end{array}$ & $98(87.5)$ & $85(92.4)$ & 183(89.7) \\
\hline $\begin{array}{l}\text { Medical students should be vaccinated } \\
\text { within 1year of joining school }\end{array}$ & $96(85.7)$ & $88(95.6)$ & 184(90.2) \\
\hline $\begin{array}{l}\text { Willing to receive or complete their } \\
\text { Hepatitis } B \text { vaccination }\end{array}$ & 106(94.6) & $88(95.6)$ & 194(95.1) \\
\hline $\begin{array}{l}\text { Willing to recommend Hepatitis B } \\
\text { Vaccination to medical friends }\end{array}$ & $78(69.6)$ & $83(90.2)$ & 161(78.9) \\
\hline
\end{tabular}

\section{Practices towards Hepatitis B vaccination:}

Majority comprising of 175 (85.8\%) respondents had poor practice against Hepatitis B infection and vaccination. The mean practice score of the study subjects was $40.34 \pm 23.81$ (Table 2).

Only 77 (37.7\%) respondents had screened for Hepatitis B infection in the past. One hundred and twenty (58.8\%) clinical medical students had vaccinated at least once. But complete doses of 3 vaccines were received by only $96(47.1 \%)$ medical students. Twenty four (11.7\%) medical students were partially vaccinated against Hepatitis B Virus infection. Eighty four (41.2\%) medical students were never vaccinated. Among the respondents, only $28(13.7 \%)$ participants had screened for their Hepatitis B status just before vaccination and $19(9.3 \%)$ checked their immune status post vaccination (Table 4). Among the respondents, 130 (63.7 \%) medical students had participated in some form of educational program or campaign against Hepatitis B.

\section{Factors associated with non vaccination against Hepatitis B}

A total of $84(41.2 \%)$ clinical medical students had never received even a single dose of hepatitis $B$ vaccine. The most common reason for non vaccination described by 40 (47.6\%) medical students was that they thought they will vaccinate in internship or when they start practicing. The other reasons mentioned were negligence by

Table 4: Practices towards Hepatitis B vaccination in study participants

\begin{tabular}{|l|l|l|l|}
\hline Practice towards Hepatitis B Vaccination & $\begin{array}{l}\text { 3rd MBBS (N=112) } \\
\text { Correct (\%) }\end{array}$ & $\begin{array}{l}\text { 4th MBBS (N=92) } \\
\text { Correct (\%) }\end{array}$ & $\begin{array}{l}\text { Total (N=204) } \\
\text { Correct (\%) }\end{array}$ \\
\hline $\begin{array}{l}\text { Have you screened for Hepatitis B } \\
\begin{array}{l}\text { Have you participated in any educational program or } \\
\text { campaign on Hepatitis B }\end{array}\end{array}$ & $36(32.1)$ & $41(44.6)$ & $77(37.7)$ \\
\hline $\begin{array}{l}\text { Received Hepatitis B vaccine (at least once) } \\
\text { Received complete Hepatitis B vaccine }\end{array}$ & $64(75)$ & $46(50)$ & $130(63.7)$ \\
\hline $\begin{array}{l}\text { Screened for Hepatitis B just before vaccination } \\
\text { Checked immune status (Anti HbS) after vaccination }\end{array}$ & $52(46.4)$ & $56(58.3)$ & $120(58.8)$ \\
\hline
\end{tabular}


Table 5: Association between Characteristic of Respondents and levels of KAP

\begin{tabular}{|c|c|c|c|c|}
\hline \multicolumn{2}{|l|}{ Variables } & Good & Bad & Statistics \\
\hline \multicolumn{5}{|c|}{ Knowledge of Medical students } \\
\hline \multicolumn{2}{|l|}{ Male } & 118 & 4 & \multirow{2}{*}{$\begin{array}{l}\text { Chi sq. test }=0.92 ; d f=1 \\
p=0.336\end{array}$} \\
\hline \multicolumn{2}{|l|}{ Female } & 77 & 5 & \\
\hline \multicolumn{2}{|l|}{ 3rd MBBS } & 107 & 5 & \multirow{2}{*}{$\begin{array}{l}\text { Chi sq. test }=0.46 ; d f=1 \\
p=0.968\end{array}$} \\
\hline \multicolumn{2}{|l|}{ 4th MBBS } & 88 & 4 & \\
\hline \multicolumn{5}{|c|}{ Attitude of Medical students } \\
\hline \multicolumn{2}{|l|}{ Male } & 119 & 3 & \multirow{2}{*}{$\begin{array}{l}\text { Chi sq. test }=0.24 ; d f=1 \\
p=0.619\end{array}$} \\
\hline \multicolumn{2}{|l|}{ Female } & 79 & 3 & \\
\hline \multicolumn{2}{|l|}{$3 r d$ MBBS } & 106 & 6 & \multirow{2}{*}{$\begin{array}{l}\text { Chi sq. test }=5.078 ; d f=1 \\
p=0.024\end{array}$} \\
\hline \multicolumn{2}{|l|}{ 4th MBBS } & 92 & 0 & \\
\hline \multicolumn{5}{|c|}{ Practice of Medical students } \\
\hline Male & \multicolumn{2}{|l|}{21} & 101 & \multirow{2}{*}{$\begin{array}{l}\text { Chi sq. test }=2.23 ; d f=1 \\
p=0.135\end{array}$} \\
\hline Female & \multicolumn{2}{|l|}{8} & 74 & \\
\hline 3rd MBBS & \multicolumn{2}{|l|}{93} & 19 & \multirow{2}{*}{$\begin{array}{l}\text { Chi sq. test }=1.53 ; d f=1 \\
p=0.215\end{array}$} \\
\hline 4th MBBS & 82 & & 10 & \\
\hline
\end{tabular}

24(28.6\%) medical students followed by not really felt or realized by $8(9.5 \%)$, afraid of injection by $6(7.1 \%)$ and rest $6(7.1 \%)$ medical students had no reasons.

All medical students of both the clinical years demonstrated good knowledge and good attitude overall. There was statistically no significant association between sex and clinical medical year against level of knowledge and attitude for hepatitis $B$ vaccination ( $p>0.05$ ) (Table 5$)$.

Despite, good knowledge and good attitude, all medical students of both clinical years showed a poor practice. There was statistically no significant association between sex and clinical medical years with practice towards Hepatitis B vaccination $(p>0.05)$.

\section{DISCUSSION}

The mean age of study participants was $22.1 \pm .2 .35$ years in the current study which is nearly similar to the study by Vasantha et al. ${ }^{8}$ with mean value of $21.05 \pm 1.14$ years. In the current study, majority (95.6\%) of the respondents had good knowledge of hepatitis B vaccination. Similar, good knowledge were demonstrated by $77.07 \%$ and $79.1 \%$ in the studies by Vasantha et al. ${ }^{8}$ and Jacob et al. ${ }^{9}$ in
India respectively. But in Senegal, majority of $73 \%$ showed poor knowledge in the study by Fortes et al. ${ }^{10}$

Among the respondents in the current study, 83.3\% knew that hepatitis B is not spread by handshaking. It was reported by $93 \%$ medical students in the study by Jacob et al. ${ }^{9}$ In the current study, $78.4 \%$ medical students knew about effective hepatitis $B$ vaccine Whereas even greater frequencies of knowledge by $86.5 \%, 89.6 \%$ and $94.6 \%$ medical students were documented in the studies by Alhowaish et al. ${ }^{11}$ in Saudi Arabia, Jacob et al. ${ }^{9}$ and Vasantha et al..$^{8}$ in India respectively.

Majority (97.1\%) of the respondents had positive attitude towards Hepatitis B vaccination. In India, studies by Vasantha et al. ${ }^{8}$, Chhabra et al. ${ }^{12}$ and Jacob et al. ${ }^{9}$ reported positive attitude by $77.56 \%$, $80.6 \%$ and $84.3 \%$ respectively. Whereas, $67.6 \%$ of the students demonstrated a poor attitude in the study by Fortes et al. ${ }^{10}$ in Senegal.

In the current study, $80.9 \%$ of the medical students believed that it was a safe vaccine and $72.1 \%$ trusted its efficacy. Even better were the findings in the study by Alhowaish et al. ${ }^{11}$ in Saudi Arabia where $86.5 \%$ believed that HBV vaccine was safe and $90 \%$ believed that following proper infection and control guidelines, it would protect them from 
HBV. Majority (85.6\%) of the respondents had bad or poor practice against Hepatitis $B$ infection and vaccination in the current study. Poor practice was common among medical students in many studies as well. It was $55.2 \%$ and $66.6 \%$ in the Indian studies by Jacob et al. ${ }^{9}$ and Vasantha et al. ${ }^{8}$

Only $37.7 \%$ had tested for Hepatitis B in the current study, whereas, more than half (56.5\%) and 55.6\% had screened for HBV infection in the studies by Alhowaish et al. ${ }^{11}$ and Fortes et al. ${ }^{10}$ respectively. It was even better (79.5\%) in the study by Vasantha et al. ${ }^{8}$

Many studies have demonstrated a low rate of complete vaccination among medical students. In the current study, $58.8 \%$ clinical medical students had vaccinated at least once but complete vaccines were received by only $47.1 \%$. Among the respondents, $48.5 \%$ were immunized at least once but complete vaccination were received by only $34.5 \%$ in the study by Jacob et al. ${ }^{9}$ In a similar study by Chhabra et al. ${ }^{12}, 82.8 \%$ students underwent vaccination but only $62.4 \%$ completed the recommended three doses of vaccination schedule. In a similar study by Alhowaish et al. ${ }^{11}, 69.5 \%$ had received $\mathrm{HBV}$ vaccine but only $38 \%$ of them had received the complete doses respectively. This rate of complete vaccination was comparatively higher, $88.1 \%$ by Kabir et al. ${ }^{13}$ in Iran and $87.8 \%$ by Muhammad et al. ${ }^{14}$ in Pakistan. Studies by Raza et al. ${ }^{15}$ in Pakistan, Vasantha et al. ${ }^{8}$ in India and Fortes et al. ${ }^{10}$ in Senegal suggested that $80.6 \%, 79.5 \%$ and $61.3 \%$ of the students were fully vaccinated respectively. At the other hand, very low, i.e. only $8 \%$ and $2 \%$ of the medical students were fully vaccinated in the studies by Rathi et al. ${ }^{16}$ and Abdela et al. ${ }^{17}$ respectively.

Studies have also demonstrated tendency of incomplete vaccination among medical students. In the current study, $11.7 \%$ students were partially vaccinated against Hepatitis B Virus infection whereas $20.5 \%$ and $18.7 \%$ were partially vaccinated in the Indian studies by Vasantha et al. ${ }^{8}$ and Rathi et al. ${ }^{16}$ respectively. In our current study, $41.2 \%$ were never vaccinated against Hepatitis B whereas, even a larger mass of $73.3 \%$ was not vaccinated in the Indian study by Rathi et al. ${ }^{16}$ All these studies suggest that majority of medical students despite having adequate knowledge and good practice regarding hepatitis infection and importance of vaccination, however many are not vaccinated. Those who get vaccinated, some of them fail to complete the recommended schedule.

The most common reason for non vaccination in the current study described by $47.6 \%$ was that they thought they will vaccinate in internship. The other reasons were negligence in $28.6 \%$ followed by felt no necessity or not realized in $9.5 \%$, afraid of injection in $7.1 \%$ and rest $7.1 \%$ had no reasons. The common reasons were lack of information by $39.3 \%$, not felt necessity in $35.6 \%$, negligence in $22 \%$ and fear of injection in $2.9 \%$ in the Yemenian study by Almulam et al., ${ }^{18}$ reasoning almost similar to ours.

The practice of testing for antibodies for confirming immunization post vaccination was even very low among the medical students. Among the respondents in the current study, only $9.3 \%$ had checked their immune status post vaccination. It was only $7 \%$ according to the study by Chhabra et al. ${ }^{12}$ Among the respondents, $63.7 \%$ had participated in some form of educational program or campaign against Hepatitis B .whereas, only $17.8 \%$ and $8.8 \%$ had participated in such programs according to Jacob et al. ${ }^{9}$ and Almulam et al. ${ }^{18}$ respectively .

This study had its own limitations. The study reflects the knowledge, attitude and practice of a group of MBBS clinical medical students of a medical school which may not be uniform to all medical students within the country. Larger sample size with multi centers study is recommended.

\section{CONCLUSION}

Despite the good knowledge and positive attitude towards Hepatitis B infection and vaccination, many medical students have poor practice towards it indicating the necessity of encouragement for vaccination and proper practices among them.

All medical students should be protected and immunized against Hepatitis B followed by confirmation of immunization with post vaccination antibodies testing before their occupational exposure in hospitals and their practices. Regular Hepatitis B vaccination, educational and awareness programs with active participation of the medical students are highly recommended.

Acknowledgements: The authors take this opportunity to thank all the MBBS undergraduate medical students of Manipal College of Medical sciences, Pokhara, Nepal.

\section{REFERENCES}

1. Schillie S, Murphy TV, Sawyer M, Ly K, Hughes $E$, Jiles $R$ et al. CDC guidance for evaluating healthcare personnel for Hepatitis B virus protection and for administering post exposure management. 
Recommendations and Reports. Morbidity and mortality weekly report. 2013; 62(10):1-19. [ PubMed ] | [ Full Text ]

2. Lavanchy D. Hepatitis B virus epidemiology, disease burden, treatment, arid current and emerging prevention and control measures. Journal of Viral Hepatitis. 2004; 11(2):97-107. https://doi. org/10.1046/j.1365-2893.2003.00487.x [PubMed] | [ Full Text ]

3. Ott JJ, Stevens GA, Groeger J, Wiersma ST. Global epidemiology of hepatitis B virus infection: new estimates of age-specific HBsAg seroprevalence and endemicity. Vaccine 2012; 30(12): 2212-19. https:// doi.org/10.1016/j.vaccine.2011.12.116 [ PubMed] | [Full Text ]

4. Rawal B, Deuba K, Kakchapati S, Amgain K, Sanjel S. Prevalence of HIV, Syphilis, Hepatitis-B, and Hepatitis-C among People with Injecting Drugs in Western Terai Highway districts, Nepal. Journal of Karnali Academy of Health Sciences. 2019 Aug 6;2(2):98-106. http://doi.org/10.3126/jkahs. v2i2.25168 [ Full Text ]

5. Rogers B, Goodno L. Evaluation of interventions to prevent needle stick injuries in health care occupations. Am J Prev Med. 2000; 18(4):90-98. https://doi.org/10.1016/S0749-3797(00)00145-8. [PubMed ] | [Full Text ]

6. Colin WS, Simard EP, Finelli $L$, Fiore $A E$, Bell $B P$. Hepatitis B virus infection: epidemiology and vaccination. Epidemiologic Reviews.2006; 28(1):11225. $\quad$ https://doi.org/10.1093/epirev/mxj009 [PubMed] | [Full Text ]

7. WHO Global Hepatitis Report 2017. Available at https://www.who.int/publications-detail/globalhepatitis-report-2017. [ Full text ]

8. Vasantha Mallika MC, Sivaanusuya S. Knowledge, attitude and practice on prevention of Hepatitis $B$ infection among medical students of a tertiary care centre in Tamil Nadu, India Int J Res Med Sci. 2020; 8(2):492-96. https://dx.doi.org/10.18203/2320-6012. ijrms20200223 [ Full Text ]

9. Jacob A, Joy TM, Mohandas S, Lais H, Paul N . Assessment of knowledge, attitude, and practice regarding Hepatitis $B$ among medical students in a private medical college in Kochi. Int J Community Med Public Health.2019; 6(5):1938-42. https:// dx.doi.org/10.18203/2394-6040.ijcmph20191552 [ Full Text ]

10. Fortes Déguénonvo L, Massaly A, Ngom Gueye NF, Diallo Mbaye K, Cisse Diallo VMP, Lakhe NA et al. Assessment of knowledge, attitudes and practices of medical students regarding Hepatitis B infection at a private university of medicine in Senegal. J Infect Dis Epidemiol.2019; 5(6):103-10. https://doi.org/ 10.23937/2474-3658/1510103 [ Full Text ]

11. Alhowaish $M A$, Alhowaish J A, Alanazi $Y H_{\text {, }}$ Alshammari M M, Alshammari M S, Alshamari $N$ $G$ et al. Knowledge, attitudes and practices toward prevention of Hepatitis B virus infection among medical students at Northern Border University, Arar, Kingdom of Saudi Arabia. Electron Physician. 2017; 9(9): 5388- 94. https://doi.org/10.19082/5388 [ PubMed ] | [ Full Text ]

12. Chhabra D, Mishra S, Gawande K, Sharma A, Kishore $\mathrm{S}$, Bhadoria AS. Knowledge, attitude, and practice study on Hepatitis B among medical and nursing undergraduate students of an apex healthcare institute at Uttarakhand foothills: A descriptive analysis. J Family Med Prim Care 2019; 8(7):2354-60. https://doi.org/ 10.4103/jfmpc.jfmpc 33119 [ Full Text ]

13. Kabir A, Tabatabaei SV, Siamak Khaleghi, Agah S, Kashani AH, Moghimi $\mathrm{M}$ et al. Knowledge, attitudes and practice of Iranian medical specialists regarding hepatitis B and C. Hepatitis Monthly. 2010; 10(3):17682. [ PubMed ] | [ Full Text ]

14. Muhammad A, Zulfikar AG, Raza W. Hepatitis B vaccination coverage in medical students at a medical college of Mirpurkhas. Journal of Pakistan Medical Association. 2011; 61(7): 680-82. [ PubMed] | [ Full Text ]

15. Raza W, Tariq W, Zafar Z, Ali I, Khar MU, Khurram M. Knowledge, attitude and practices (KAP) of medical students towards Hepatitis B and C. Ann Pak Inst Med Sci. 2008; 4(2):116-20. [ Full Text ] [ Weblink ]

16. Rathi A, Kumar V, Majhi J, Jain $S$, Lal $P$, Singh $S$. Assessment of knowledge, attitude, and practices toward prevention of Hepatitis B infection among medical students in a high-risk setting of a newly established medical institution. J Lab Physicians 2018; 10(4):374-79. https://doi.org/ 10.4103/JLP. JLP 9318 [ PubMed] | [Full Text]

17. Abdela A, Woldu B, Haile K, Mathewos B, Deressa $\mathrm{T}$. Assessment of knowledge, attitudes and practices toward prevention of hepatitis B virus infection among students of medicine and health sciences in Northwest Ethiopia .BMC Res Notes 2016; 9:41018. https://doi.org/ 10.1186/s13104-016-2216-y [ PubMed ] | [ Full Text ]

18. Almualm YK, Banafa NS, Abdulla SH. Knowledge, attitude and practice (KAP) about Hepatitis B and C among Students of Hadhramout University, AlMukalla City, Yemen. Acta Scientific Medical Sciences 2018; 2(7): 87-95. [ Full Text ] 